\title{
Becoming a Science Teacher in Texas
}

\author{
Hsin-Hui Lin, Ph. D. \\ Associate Professor \\ Department of Teacher Leadership and New Literacies \\ University of Houston at Victoria \\ 3007 N. Ben Wilson, Victoria, TX, USA 77901 \\ E-mail: linh@uhv.edu
}

Received: Feb. 9, 2013

Accepted: April 4, 2013 Published: May 1, 2013

doi:10.5296/jse.v3i2.3243

URL: http://dx.doi.org/10.5296/jse.v3i2.3243

\begin{abstract}
This study analyzes the competency of science teachers as it pertains to the passage of the TExES Content Exam. Teacher qualification is determined by the results of standardized tests because of the accountability standards imposed by No Child Left Behind (NCLB). Teacher qualification is determined by state mandated standardized tests. In 2012 the State Board of Education adopted changes to high school graduation requirements that mandates four years of science for those students in the recommended and distinguished achievement high school programs. This change has added an urgency to teacher preparation programs to certify even more qualified science teachers. The results of this study may guide policy makers to improve the preparation of science teachers by determining the areas in which effort and support is most needed.
\end{abstract}

Keywords: Standardized testing, Teacher education programs, TExES Science exams, State certification, Science teacher 


\section{Introduction}

Parents and the public in general believe that teachers are qualified to teach. The criteria by which teachers are determined "highly qualified" are generally not questioned. The current status of science preparation of US students has, however, been cause for concern (Rich 2012).

These concerns have increased over the last decade. In 2006, a study by the Program for International Student Assessment (PISA) indicated that 15-year-olds from the United States were outranked by their peers in many industrialized countries in both math and science (Glod, 2007). The number of US students in engineering, science, and medicine are also declining (Nusca, 2010). Without intervention it has been predicted that the U.S. will continue to lose ground internationally (Glod, 2007).

One solution to address this issue was implemented in 2012, when the Texas State Board of Education raised graduation standards from three years of science to four for all graduation programs beyond the minimum (TEA, 2009).

Another solution is to analyze effective teaching techniques in order to determine which factors were significant in helping students' academic achievement. Research was performed on how class size, relative to teaching performance, affected student academic performance. Results indicated that a student's teacher was more influential on student achievement gains than any other factor (Darling-Hammond, 2004, Rivkin, Hanushek, \& Kain, 2000; Sanders \& Rivers, 1996; Wright, Horn, \& Sanders, 1997).

Several factors were examined to determine the efficacy of a classroom teacher's teaching, the teacher's general academic background, knowledge of teaching pedagogy, subject matter knowledge, and the teacher's verbal ability, teaching experience, and the teaching certification (Darling-Hammond, 2000; Wilson, Floden, \& Ferrini-Mundy, 2001). Results from similar studies indicate that the quality of the teacher certification program from which the teacher graduated, including the number of teachers certified as opposed to those on probationary certification, was a stronger predictor of student achievement than teacher experience (Betts, Rueben, \& Dannenberg, 2000; Fetler, 1997; Goe, 2002).

Research has revealed a correlation between teacher preparation in the academic subject matter and its' impact on student performance (Wilson, Floden, \& Ferrini-Mundy, 2001). Researchers have found that not all pre-service teachers were well grounded in the academic subjects in which they are seeking certification; examples would be math and science. Pre-service teachers may major in disciplines other than the ones in which they are certified ( for example, psychology) then complete the required course work and pass the exams for teacher certification without having built sound knowledge of the academic concepts and reasoning skills. The lack of depth in content knowledge hinders effective teaching (Wilson, Floden, \& Ferini-Mundy, 2001).

Given the importance of certified teachers in education, it is appropriate to examine the requirements for becoming a teacher in Texas. The basic requirements for obtaining Texas teaching certification are: 
- A person must have a bachelor's degree from an accredited college or university.

The only exemption from the degree requirement is for individuals seeking Career and Technology certification to teach Vocational courses such as welding.

- A person must complete teacher training through an approved program.

These programs are offered through colleges and universities, school districts, regional service centers, community colleges, and other entities.

- A person must successfully complete the appropriate tests for the subject and grade level for which certification is sought. These two tests are the TExES Content Exam, which tests the knowledge of the content area being taught, and the Pedagogy and Professional Responsibility (PPR), which tests the candidate's knowledge of such competencies as classroom management and knowledge of legal issues. (State Board for Educator Certification SBEC, 2012a)

When school districts hire teachers who have not completed all the requirements listed above, these non-certified teachers are allowed to use probationary certifications and teach in the classroom until they fulfill the requirements.

Texas State currently issues certificates in the following areas (including but not limited to):

- $\quad$ Early childhood through grade 6

- $\quad$ Grade 4 through grade 8

- $\quad$ Grade 8 through grade 12

- All level certificates (Early childhood through grade 12) (SBEC, 2012b)

\section{Purpose of the study}

The purpose of this study is to determine the competency of current Texas science teachers as per the standards of the state-mandated TExES Middle (4-8 grade) and High School (8-12 grade) Content Exam. By analyzing scores and comparing the pass/fail ratios on the science subject tests; Science 4-8, Chemistry 8-12, Life Science 8-12, Physical Science 8-12, and Science 8-12, a conclusion may be made as to which content areas teachers do well in and in which areas they need additional support. An examination of the present status of the pass/fail ratio on the TExES middle and high school content exams may enable teacher certification entities to better prepare candidates to pass the TExES science subject exams.

\section{Research Questions}

In order to examine the present status of the pass/fail rate of teachers taking the Science 4-8, Chemistry 8-12, Life Science 8-12, Physical Science 8-12, and Science 8-12, the following research questions were posed:

- What were the passing rates of the TExES Science 4-8 exam of teachers?

- What were the passing rates of the TExES Chemistry 8-12 exam of high school teachers? 


\section{Macrothink}

- What were the passing rates of the TExES Life Science 8-12 exam of teachers?

- What were the passing rates of the TExES Physical Science 8-12 exam of teachers?

- What were the passing rates of the TExES Science 8-12 exam of teachers?

- What was the number of attempts that the teachers made to pass the TExES science content exams?

\section{Methodology}

This study investigates the TExES test scores during a four and one-half year period. Data for this study was obtained from Texas State Teacher Certification test records, which were posted on websites broadcasted on the ABC news network (ABC 13, 2007) in Houston and KDFW Fox News in Dallas (KDFW, 2007) in 2007. By accessing these websites, the authors were able to obtain the TExES scores and the number of testing attempts of all teachers who took the TExES test in 82 school districts throughout the state. This study utilized the testing records to investigate the teachers' test results in the content areas of Science 4-8, Chemistry 8-12, Life Science 8-12, Physical Science 8-12, and Science 8-12 (Texas Education Agency, 2009).

\section{Data File}

The original data included last name, first name, middle name, the district where the individual worked, position held within the district (such as teacher), test description (such as Science 4-8, Chemistry 8-12, Life Science 8-12, Physical Science 8-12, and Science 8-12), test date, test results (passed or failed), and test scores. For each attempt of the test an individual took, (s)he would have one line of data in the spreadsheet. If a person took a test five times, (s)he would have each testing encounter recorded on a separate line, for a total of five lines.

The testing records obtained from the websites were pdf files. The researcher used Adobe Acrobat 8 software - professional version to convert the files from pdf format to Excel files. Then, Microsoft Access software was used to develop an identification number for each individual. Using the ID, the researchers were able to build a relational database to prepare the data files for further statistical analyses.

Two different examinations of TExES high school science teacher certification are available which is related to physical content, Mathematics/Physics 8-12 and Physics 8-12. We combined these two tests and make them into one category as Physics 8-12.

\section{Data Analysis and Interpretation}

\section{A. Independent Variables}

There were two independent variables; certification test and test group. Certification tests included Science 4-8, Chemistry 8-12, Life Science 8-12, Physical Science 8-12, and Science 8-12. Three test groups were created based on the results of the individual's most recent test performance on the each certification exam. 


\section{Macrothink}

- “Passed" is the group of people who took the certification exam and were able to pass on their first attempt.

- "Failed/Passed" is the group of people who took the certification exam and failed at least one attempt before they finally passed the exams.

- "Failed" is the group of people who had made attempts of the test and still were not able to pass the test.

\section{B. Dependent Variable}

Test results of passed or failed and the number of the attempts when taking the certification tests were the dependent variables.

\section{Analyses}

All the statistical analyses were conducted by using IBM Statistical Package for Social Science (SPSS 20) for Windows. Descriptive analyses, a chi-square test, and an ANOVA test were conducted for studying the research questions. A chi-square test was conducted to test the independent distribution among the three test groups within each certification exam. A two-way ANOVA model was applied to the two main effects (certification test and test group) and the interaction effect (certification test $\mathrm{x}$ test group).

\section{Results}

Table 1 indicates the descriptive analyses of middle and high school Teachers' TExES science exam results. There were 738 individuals that took the middle school science teacher certification exam (Science 4-8). Among the high school science teacher certifications, Science 8-12 has the most number of people took the test $(n=647)$, followed by Life Science 8-12 ( $\mathrm{n}=513)$, Physical Science 8-12 ( $\mathrm{n=291)}$, and Chemistry 8-12 ( $\mathrm{n}=27)$.

The distribution among the three test groups - passed, failed/passed, and failed - in each certification test is listed below.

Science 4-8. Sixty-five percent of the teachers taking the Science 4-8exam passed the first time (passed group 65\%). The group that failed/passed and the group that failed have almost the same rate (Passed/Failed 17\% and Failed 18\%).

Chemistry 8-12. Fifty-nine percent of the teachers taking the Chemistry 8-12 exam passed the first time (passed group 59\%). The failed/passed group was $11 \%$ and the failed group was $30 \%$.

Life Science 8-12. Fifty-five percent of the teachers taking the Life Science 8-12 exam passed the first time (passed group 55\%). The failed/passed group was 19\% and the failed group was $26 \%$.

Physical Science 8-12. Sixty-four percent of the teachers taking the Physical Science 8-12 exam passed the first time (passed group 64\%). The failed/passed group was $9 \%$ and the failed group was $27 \%$. 
Science 8-12. Forty-six percent of the teachers taking the Science 8-12 exam passed the first time (passed group 46\%). The failed/passed group was $20 \%$ and the failed group was $34 \%$.

A chi-square test was conducted to test the independent distribution among the three test groups within each certification exam. The results obtained proved to be statistically significant $\left(X^{2}=77.81, d f(8)\right.$ and $\left.p<.001\right)$.

Table 2 shows the number of attempts that each individual made on the science certification exams. For the passing group, the average of attempt was one. In other words, they passed the test on their first attempt. However, for the failed/passed and failed groups the results varied. Detailed results were reported as follows:

Science 4-8. For the failed/passed group, the mean number of attempts of taking the Science 4-8 exam was 2.94 with the range of 2 to 10 while the failed group had a mean number of attempts equal to 1.85 .

Chemistry 8-12. For the failed/passed group, the mean number of attempts of taking the Chemistry 8-12 exam was 2.00 while the failed group had a mean number of attempts equal to 1.38 .

Life Science 8-12. For the failed/passed group, the mean number of attempts of taking the Life Science 8-12 exam was 3.11 with the range of 2 to 10 while the failed group had a mean number of attempts equal to 1.73 .

Physical Science 8-12. For the failed/passed group, the mean number of attempts of taking the Physical Science 8-12 exam was 2.73 with the range of 2 to 6 while the failed group had a mean number of attempts equal to 1.40 .

Science 8-12. For the failed/passed group, the mean number of attempts at taking the Science 8-12 exam was 3.33 with the range of 2 to 11 while the failed group had a mean number of attempts equal 1.85 .

In order to test the two main effects (certification type and test group) and the interactions between them, an ANOVA test was done. Results show that type of certification and test group correlated significantly with the number of attempts taking the test; in other words, the differences between type of certification and test group were noteworthy. The comparison of type of certification test was statistically significant $\left[F(4,2201)=5.28^{* * *}, p<.001\right]$. The comparison of test group was statistically significant $\left[F(2,2201)=96.85^{* * *}, p<.001\right]$. Finally, the comparison of the interaction between type of certification test and test group was statistically significant $\left[F(8,2201)=2.85^{* *}, p<.01\right]$ (see table 3$)$.

\section{Discussion}

In Texas, teachers who want to teach science in middle school have two options to obtain their teaching certification. One is to go through 4-8 generalist certification and another is to science 4-8. Still within a little more than four years period, only 608 teachers were certified to teach middle school science within the 82 school districts. On the average, only a little more than seven teachers per school district were added to the teaching pool. 
Comparing all the high school science teacher certification exams, most people took the Science 8-12 test ( $n=647)$, while least among of the teachers took Chemistry 8-12 test $(n=27)$. The passing rate for test two certification tests, both of them was around $70 \%$ (passed plus failed/passed rates). Looking at this big discrepancy among these two groups, only 19 teachers passed the Chemistry 8-12 certification test. This result revealed that Texas might have a severe problem with Chemistry teacher shortage.

The results indicated that the passing rates were different among these five science teacher certification exams. Among the high school teacher certification exams, physical science 8-12 had the highest first time passing rate of 64\%, while the Science 8-12 had the lowest first time passing rate (46\%). In the meantime, looking at the high school teachers who failed the test, the ratio were all close to $30 \%$, which indicated that one out of three individuals could not pass the high school science teacher certification exams (See figure 1).

When we investigated the numbers of attempts at taking the TExES middle and high school science teacher certification tests, the failed/passed groups averaged around three attempts before passing the tests, excluding the Chemistry 8-12 group. Within these four tests, people who took the Physical Science 8-12 had the lowest average number of attempts ( $M=2.73)$, while the Science 8-12 had the highest average number of attempts $(\mathrm{M}=3.33)$.

\section{Conclusion}

The research results suggest that individuals had difficulty passing TExES middle and high school science teacher certification. Teacher preparation programs should examine their curriculum to include adequate, quality preparation of science subjects. The lower science passing rates in 4-8 as well as in 8-12 exams indicate that more resources may need to be added to these subject areas.

Research results suggest the difficulties that a large percentage of pre-service teachers experience in passing the science content exams can be attributed to lack of science content preparation. Teacher preparation programs should examine their curriculum to include adequate, quality preparation of science subjects. The lower science passing rates in 4-8 as well as in 8-12 exams indicate that more resources may need to be allocated to these subject areas.

Given the higher percentages of teachers who have failed the Science content exams at least once and perhaps multiple times, school districts should consider intensive and continuous professional development for science teachers.

\section{References}

ABC 13, (2007). 13 undercover investigates teachers' test scores. Retrieved May 15, 2007, from http://abclocal.go.com/ktrk/story?section=investigative\&id=5290451

Betts, J. R., Rueben, K. S., \& Danenberg, A. (2000). Equal resources, equal outcomes? The distribution of school resources and student achievement in California. San Francisco: Public Policy Institute of California. Retrieved February 9, 2011, from http://www.ppic.org/main/pressrelease.asp?i=334 
Teacher quality and student achievement: A review of state policy evidence. Educational Policy Analysis Archives, 8(1). Retrieved January 7, 2013, from http:// http://epaa.asu.edu/ojs/article/view/392/515.

Darling-Hammond, L (2004). Inequality and the right to learn: Access to qualified teachers in California's public schools. Teachers College Record, Vol. 106 (10), 1936-1966. Retrieved January 7, 2013, from http://www.srnleads.org/data/pdfs/ldh_achievemen_gap_summit/inequality_TCR.pdf

Fetler, M. (1997). Where have all the teachers gone? Education Policy Analysis Archives, 5(2), Retrieved January 7, 2013, from http://epaa.asu.edu/ojs/article/view/603/725

Goe, L. (2002). Legislating equity: The distribution of emergency permit teachers in California. Berkeley: Graduate School of Education, University of California, Berkeley.

Glod, M. (2007, December 5) U.S. teens trail peers around world on math-science test. Washington Post. Retrieved June 20, 2011, from http://www.washingtonpost.com.

KDFW (2007). KDFW Fox News in Dallas: Educators repeatedly flunk required exams. Retrieved June 23, 2007, from http://www.myfoxdfw.com/myfox/pages/Home/Detail; jsessionid=707BC28CFF69375439C05169B39AB8C0 contentId=3205107\&version=9\& locale=EN-US\&layoutCode=TSTY\&pageId=1.1.1\&sflg=1

Rich M. (2012). U.S. students still lag globally in math and science, tests show. New York Time. Retrieved January 28, 2013, from http://www.nytimes.com/2012/12/11/education/us-students-still-lag-globally-in-math-and-scie nce-tests-show.html?_r=0

Nusca, A. (2010) DARPA: 'Significant decline' in U.S. science, tech degrees 'harming national security'. Retrieved January 28, 2013, from http://www.smartplanet.com/blog/smart-takes/darpa-8216significant-decline-in-us-science-te ch-degrees-8216harming-national-security/3412

Rivkin, S. G., Hanushek, E. A., \& Kain, J. F. (2000). Teachers, schools, and academic achievement (Working paper No. 6691). Cambridge, MIA: National Bureau of Economic Research.

Sanders, W. L., \& Rivers, J. C. (1996). Cumulative and residual effects of teachers on future student academic achievement. Knoxville: University of Tennessee Value-Added Research and Assessment Center.

State Board of Education (SBEC) (2012a). How to become a teacher in Texas? Retrieved June 18, 2012, from http://www.sbec.state.tx.us/sbeconline/certinfo/becometeacher.asp?width=1093\&height=614

State Board of Education (SBEC) (2012b). Study guides and preparation manual. Retrieved June 18, from 2012 http://www.texes.ets.org/prepMaterials/

Texas Education Agency (October, 2009). Texas Educator Certification Program: TExES Tm 


\section{Macrothink}

Journal of Studies in Education

ISSN 2162-6952 2013, Vol. 3, No. 2

Faculty Manual Retrieved June 20, 2011, from http://www.texes.ets.org/assets/pdf/testprep_manuals/texes_faculty_manual.pdf

Wilson, S., Floden, R., \& Ferrini-Mundy, J. (2001). Teacher preparation research: Current knowledge, gaps, and recommendations. Seattle: University of Washington Center for the Study of Teaching and Policy. Retrieved January 28, 2013, from ttp://www.stcloudstate.edu/tpi/initiative/documents/preparation/Teacher\%20Preparation\%20 Research-Current\%20Knowledge,\%20Gaps,\%20and\%20Recommendations.pdf

Wright, S. P., Horn, S. P., \& Sanders, W. L. (1997). Teacher and classroom context effects on student achievement: Implications for teacher evaluation. Journal of Personnel Evaluation in Education, 11, 57-67.

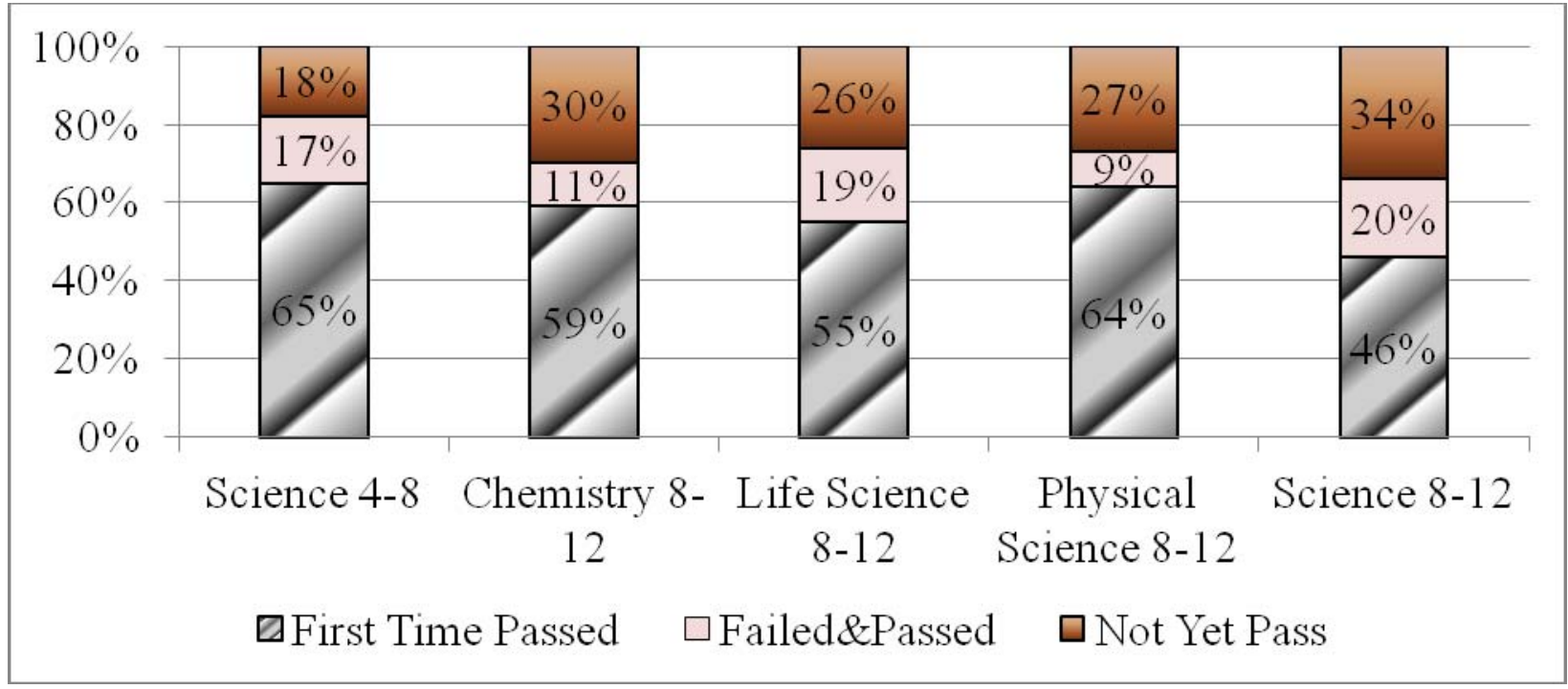

Figure 1. Test Results by Each Science Subject Test 
Table 1. The Descriptive Analyses of Middle and High School Science Teachers' TExES Exam Results

\begin{tabular}{|c|c|c|c|c|c|c|c|c|}
\hline \multirow[b]{2}{*}{ Certification Test } & Total & \multirow[b]{2}{*}{ Individual } & \multicolumn{2}{|l|}{ Passed } & \multicolumn{2}{|c|}{ Failed/Passed } & \multicolumn{2}{|l|}{ Failed } \\
\hline & Records & & $\mathrm{n}$ & M & $\mathrm{n}$ & M & $\mathrm{n}$ & M \\
\hline Science 4-8 & 1093 & 738 & 482 & $65 \%$ & 126 & $17 \%$ & 130 & $18 \%$ \\
\hline Chemistry 8-12 & 33 & 27 & 16 & $59 \%$ & 3 & $11 \%$ & 8 & $30 \%$ \\
\hline Life Science 8-12 & 820 & 513 & 280 & $55 \%$ & 99 & $19 \%$ & 134 & $26 \%$ \\
\hline Physical Science 8-12 & 372 & 291 & 187 & $64 \%$ & 26 & $9 \%$ & 78 & $27 \%$ \\
\hline Science 8-12 & 1141 & 647 & 298 & $46 \%$ & 131 & $20 \%$ & 218 & $34 \%$ \\
\hline
\end{tabular}

Table 2. Number of Attempts of Taking the TExES Exam for the Comparison Groups

\begin{tabular}{lrrrrrrrrr}
\hline & \multicolumn{4}{c}{ Failed/Passed } & \multicolumn{7}{c}{ Failed } \\
\cline { 2 - 9 } Certification Test & M & SD & Min & Max & M & SD & Min & Max \\
\hline Science 4-8 & 2.94 & 1.34 & 2 & 10 & 1.85 & 1.76 & 1 & 11 \\
Chemistry 8-12 & 2.00 & 0.00 & 2 & 2 & 1.38 & 1.06 & 1 & 4 \\
Life Science 8-12 & 3.11 & 1.62 & 2 & 10 & 1.73 & 1.30 & 1 & 9 \\
Physical Science 8-12 & 2.73 & 1.04 & 2 & 6 & 1.40 & 0.93 & 1 & 5 \\
Science 8-12 & 3.33 & 1.63 & 2 & 11 & 1.85 & 1.61 & 1 & 10 \\
\hline
\end{tabular}

Table 3. Two-Way ANOVA Test the Effects of Certification Type and Test Group on Attempts of Taking Science Exams

\begin{tabular}{|c|c|c|c|c|c|}
\hline Source & $\begin{array}{l}\text { Type III Sum of } \\
\text { Squares }\end{array}$ & $\mathrm{df}$ & Mean Square & $\mathrm{F}$ & Sig. \\
\hline Corrected Model & $1346.260^{\mathrm{a}}$ & 14 & 96.161 & 99.858 & $<.001$ \\
\hline Intercept & 1184.178 & 1 & 1184.178 & 1229.704 & $<.001$ \\
\hline Certification & 20.349 & 4 & 5.087 & 5.283 & $<.001$ \\
\hline TEST GROUP & 186.522 & 2 & 93.261 & 96.847 & $<.001$ \\
\hline $\begin{array}{l}\text { CERTIFICATION * } \\
\text { TEST GROUP }\end{array}$ & 21.964 & 8 & 2.746 & 2.851 & 0.004 \\
\hline Error & 2119.516 & 2201 & 0.963 & & \\
\hline Total & 8865 & 2216 & & & \\
\hline Corrected Total & 3465.776 & 2215 & & & \\
\hline
\end{tabular}

Note: $\quad$ a. $\mathrm{R}$ Squared $=.388$ (Adjusted R Squared $=.385$ )

b. Computed using alpha $=.05$

c. ${ }^{* *} \mathrm{p}<.01{ }^{* * *} \mathrm{p}<.001$ 